KS. JAN ZWIAZZEK

Archira, Bibliotek $\mathbf{j}$

i Musea Kościclne. 'T. 43: 1981

\title{
KS. PRAŁAT DR WALENTY PATYKIFWICZ (1903-1980)
}

Ulodził siẹ 11 lutego 1903 r. W mieście Praszka w powiecie wieluńskim. Rodzicami jego byli Piotr i Elłbicta z Bielawskich. Był ich najstarszym synem (mial rodzeństwo - 4 siostry i brata). Ojciec prowadzil zakład szewski w Plaszce. Do 7 roku zycia byl wychowywany w domu rodzinnym. Naukę rozpoczą $w$ dwuletniej szkole prywatnej w rodzinnej miejscowosici, a po jej ukończeniu chodzil do l’zyoddziałowej szkoły rządowej, także w Praszce. $\mathrm{Na}$ skutek zmian $w$ progrimie nauczania ukończył tę szkołę dopicro w $1917 \mathrm{r}$. Rodzice umozliwili mu dilsza nauke $w$ miejscowym prywatnym gimnazjum kocdukacyjnym, do któl'ego zacząl uczęszczać w 1917 r., a w 1922 ukończył szóstą klasę Dzięki życzliwości nauczycieli dostał się do siódmej klasy Szkoly Realnej Meskjej im. Tadcusza Kościuszki w Wieluniu. Świadectwo dojrzalości uzyskal tamze $w$ dniu 27 maja $1924 \mathrm{r}$. Oceny na świadectwie maturalnym świadczyly, ze należal do zdolnych uczniów. W okresie pobylu w szkole średniej $\mathrm{w}$ rodzinnej miejscowości pomagal także ojcu $\mathrm{w}$ warszlacie szewskim, a przebywając $w$ Wieluniu udzielal korepetycji, aby w ten sposób uzyskać niezbędne pieniądze na opłacenie mieszkania i nauki $w$ szkole. $Z$ pomoca materialną przychodzili mu także jego nauczyciele, a szczególnic Stefan Mikolajlis. Dzięki zdolnościom nie miał trudności $w$ opanowaniu materiału naukowego przewidzianego programem nauczania.

W ostatnich latach pobytu $w$ szkole średniej zdecydowal się na wstąpienie do stanu duchownego. Rodzice nie sprzeciwiali się jego zamiarowi, chociaż spodziewali się, że jako najstarszy syn zaopiekuje się młodszym rodzeŕstwem oraz będzie pomaguł w jego utrzymaniu i wychowaniu. Jednakże po rozpoczęciu studiów w Seminarium Duchownym we Wloclawku w $1924 \mathrm{r}$. musiał odbyć obowiązkową służbę wojskową. W książcczce wojskowej podano następujący jego rysopis: wzrost $157 \mathrm{~cm}$, oczy szare, wlosy ciemno-blond, nos i usta proporcjonalne, twarz owalna. $\mathrm{Na}$ począlku $1925 \mathrm{r}$. został skierowany przez władze wojskowe do szkoły podchorążych. Dopiero po ukończeniu służby wojskowej konlynuowal studia w Seminarium Duchownym we Wlockawku. W tym czasie Seminarium Duchowne we Wloclawku reprezentowalo wysoki poziom naukowy, a wśród jego prol'esorów byli wybitni przedstawiciele wiedzy teologicznej w Polsce. Tu ukończyl studia filozoficzno-leologiczne oraz otrzymal wszystkie świçcenia łącznie z diakonatem. W czasie studiów seminaryjnych wyróżniał się zdolnościami w dzicdzinie nauk historycznych. Pomagal takize $w$ pracy $w$ bibliotece Seminarium, prowadzonej przez profesora historii Kościola ks. Michala Morawskiego, skąd wyniósl duźy szacunek do książek. Po ukończeniu studiów teologicznych we Wloclawku, na skutek porozumienia zawartego pomiçdzy biskupem częstochowskim Teodorem Kubiną, a biskupem wlocławskim Wladyslawem Krynickim o możliwości przejścia absolwentów Seminarium Duchownego we Wlocławku, pochodzących z terenów diecezji częstochowskiej, do pracy kaplańskiej w diecezji częstochowskiej, 
wraz z kilku klerykami zostal ekskardynowany z diecezji włocławskiej i wlączony do kleru diecezji częstochowskiej. Świecenia kapłańskic otrzymal w dniu 9 czerwca 1929 r. w katedrze częstochowskiej z rąk biskupa Teodora Kubiny.

Jako neoprezbiter zostal wyznaczony w dniu 21 czerwca 1929 r. na stanowisko wikariusza $w$ parafii Borowno $w$ dekanacie mstowskim. Dał sie tu poznać jako gorliwy kapłan i dobry nauczyciel religii w miejscowych szkołach powszechnych. Jednakże ze względu na słaby stan zdrowia musiał poddać się systematycznemu leczeniu. Plagnąl jednocześnie pogłębić swoje studia teologiczne, na których kontynuowanie uzyskal zezwolenie władzy diecczjalnej $w$ dniu 1 pazdziernika 1931 l. Biskup Teodor Kubina mianowal go w tym czasie prefokicm w Seminarium Duchownym diecezji częstochowskiej w Krakowie. Studia specjalistyczne kontynuowal na Wydziale Teologicznym Uniwersytetu Jagiellońskiego w Klakowie. Na podstawie pracy pt. „Eugenika $w$ świetle nauki moralności katolickiej" uzyskał tytuł naukowy magistra teologii $w$ dniu 20 grudnia 1932 r. W dniu 14 lutego 1933 r. zostal mianowany wikariuszem $w$ parafii św. Barbary $w$ Częstochowie. Tu wspólpracowal $w$ duszpasterstwic $z$ ks. prakitem Marianem Nassalskim do dnia 5 listopada $1937 \mathrm{l}$., kiedy to zostal mianowany elsspozytem powstającej placówki duszpasterskiej we Wrzosowej w dekanacie częstochowskim. Organizowanie pracy parafialnej od podstaw $w$ tej miejscowości było rzeczą trudną, tym bardziej że hie istniała tu kaplica ani kościól. Zyskal subie uznanie i szacunek wiernych, a wyrazem lego bylo wyznaczenic go na kandydata na członka do Rady Gromadzkiej we Wrzosowej, na co uzyskał także pozwolenie wladzy diecezjalnej. W dniu 11 listopada 1938 r. zostal mianowany cenzorem ksiąg treści religijnej. W polowie $1939 \mathrm{r}$. władza diecezjalna zdecydowała się na odwołanie go $z$ Wrzosowej. W związlku $z$ urlopem zdrowotnym prefekta etatowego ks. mgra Ludwika Gietyngiera, uczącego religii w Państwowym Seminarium dla wychowawczyŕ przedszkoli im. Żmichowskiej w Częstochowie, biskup Kubina wyznaczyl go na stanowisko zastępczego prefekta na następny rok szkolny $w$ tym seminarium. Nominację otrzymal w dniu 9 sierpnia 1939 r. Jeszeze w dniu 28 sierpnia 1939 r., celem umożliwienia mu podjęcia obowiązków nauczyciela religii $w$ wymienionym seminarium, został mianowany kapelanem w klasztorze Sióstr Zmartwychwstania Pańskiego w Częstochowie.

Wybuch II wojny światowej uniemożliwił mu realizowanie obowiązków nauczyciela religii $\mathrm{w}$ szkole średniej oraz przeszkodzil $\mathrm{w}$ zamieszkaniu $\mathrm{w}$ Częstochowie. W tej sytuacji powrócil do Wrzosowej, ale i tutaj napotkał na duże trudności ze strony miejscowych wladz okupacyjnych. Ze względu na te trudności władza diecezjalna powierzyła mu stanowisko wikariusza w sąsiedniej parafii Poczesna $w$ dniu 9 lutego 1940 r. Jednakz̈e i $w$ tej miejscowości groziło mu niebezpieczeństwo aresztowania przez władze niemieckie. Dlatego od dnia 20 lipca $1941 \mathrm{r}$. aż do końca okupacji ukrywal się przed wladzami hitlerowskimi, najpierw w różnych miejscach na terenie Zagłębia Dąbrowskiego należącego do Prowincji Katowickiej (Prowinz Oberschlesien), a następnie we wsi Wola Wiewiecka, położonej w granicach Generalnej Guberni. Tu udało mu się zorganizować stałe nabożeństwa dla miejscowych wiernych. Na nabożeństwa do tej kaplicy przybywali także wierni z terenów wcielonych do tzw. Kraju Warty, ponieważ była to miejscowość położona tuż przy granicy Generalnej Guberni i Warthegau. Kilkakrotnie potajemnie przed 
Niemcami udzielał posługi kapłańskiej polskim partyzantom działającym w terenie nadgranicznym. Po upadku Powstania Warszawskiego zorganizowal na terenie wsi Wola Wiewiecka zbiórkę na rzecz wypędzonych mieszkańców stolicy, a dla 25 rodzin $\mathrm{z}$ Warszawy przygotowal tymczasowe mieszkania. Aby zbyinio nie ujawniać się władzom niemieckim, bardzo rzadko opuszczał miejsce zamieszkania, a nawet w zebraniach kaplanów w Radomsku tylko kilka razy wziął udział. Dużo życzliwości i pomocy okazal mu w tym czasie ks. Jan Placek, proboszcz w sąsiedniej parafii Jedino.

Po zakończeniu działań wojennych $w$ tych okolicach został mianowany w dniu 10 lutego $1945 \mathrm{r}$. administratorem parafii Wiewiec, której dotychczasowy proboszcz ks. Stanislaw Ogłaza zostal zamordowany w obozie koncentracyjnym w Dachau. Ale na tym stanowisku pracowal jedynie $w$ okresie kilku miesięcy. W dniu 13 września tr. zostal powolany do pracy $w$ Kurii Diecezjalnej w Częstochowie, na stanowisko notariusza i archiwariusza, a równocześnie został mianowany prefektem w Prywatnym Gimnazjum i Liceum dla Dorosłych w Częstochowie. Zamieszkal wówczas w klasztorze Sióstr Zmartwychwstanek w Częstochowie, w którym był kapelanem, a od 15 września tr. także prefektem w prowadzonym przez Siostry Zmartwychwstanki Gimnazjum Kupieckim i Liceum Handlowym. Na tych stanowiskach pracowal w okresie 2 lat.

W dniu 1 października 1947 r. rozpocząl pracę na stanowisku ojca duchownego w Seminarium Duchownym diecezji częstochowskiej w Krakowie. W pracy wychowawczej wśród kleryków zwracal szczególną uwagę na doniosłość liturgii w życiu kapłańskim, komentował encyklikę pap. Piusa XII „Mediator Dei” oraz podkreślał wartość każdej pracy ludzkiej. Mieszkając w Krakowie podjąl dalsze studia teologiczne, celem uzyskania stopnia naukowego doktora teologii na Wydziale Teologicznym UJ. Wynikiem jego trudów było uzyskanie tytułu doktora teologii w dniu 14 lutego 1949 r. na podstawie rozprawy z zakresu historii Kościoła pt. „Archidiakonat rudzki zwany później wieluńskim", napisanej pod lrierunkiem ks. prof. dra Tadeusza Glemmy.

Ze stanowiska ojca duchownego zostal zwolniony $w$ dniu 9 września 1950 r. i mianowany jednocześnie radcą Kurii Diecezjalnej oraz referentcm do spraw archiwalnych $w$ diecezji. Wkrótce (28 listopada tr.) powrócił na dawne stanowisko wikariusza w parafii św. Barbary w Częstochowie. Od dnia 15 września 1951 r., z nominacji biskupa Zdzisława Golińskiego, był sędzia prosynodalnym $w$ miejscowym Sądzie Biskupim. Tenże biskup częstochowski mianował go 4 lutego 1952 r. archiwariuszem Kurii Diecezjalnej. W dowód uznania dla jego postawy kapłańskiej i należytego wypełniania powierzonych mu zadań biskup Goliński mianowal go 15 maja 1953 r. kanonikiem honorowym w kapitule katedralnej w Częstochowie. W okresie, kiedy obowiązków oficjała w Sądzie Biskupim w Częstochowie nie mógł wykonywać ks. Alojzy Jatowtt (od 21 III 1953 do 5 I 1955 r.) biskup Goliński powierzył mu tymczasowe zastępstwo na urzędzie oficjała. Po uzyskaniu zgody ze strony władz administracyjnych na powtórne pełnienie obowiązków oficjała przez ks. Jatowtla, biskup Goliński odwolał go $z$ tego stanowiska wyrażając mu jednocześnie podziękowanie za ofiarną pracę w Sądzie Biskupim.

$\mathrm{Z}$ zajmowanego stanowiska wikariusza parafii św. Barbary w Częstochowie, ze względu na stan zdrowia i konieczność dłuższego leczenia, został odwołany w dniu 14 lutego 1956 r. i mianowany kapelanem w Zgromadzeniu Sióstr Zmartwychwstania Pańskiego w Częstochowie. Otızymał jednocześnie 
zadanie wizytowania ksiąg metrykalnych $w$ diecezji. W mastępnych latach zachorował bardzo ciężko na zapalenie nerwu trójdzielnego twarzy. Leczenie przebiegało długo w szpitalu klinicznym Akademii Medycznej w Krakowie oraz w klinice Akademii Medycznej - oddzial neurologiczny w Poznaniu. Jeszcze w dniu 10 sierpnia 1962 r. biskup Goliński zachęcal go w skierowanym do niego liście, aby nie przerywał leczenia. Po wyzdrowieniu powrócił do pracy $w$ Kurii Diecezjalnej jako archiwariusz. Przeprowadzal w tym czasie także egzaminy wikariuszowskie $\mathrm{z}$ zakresu historii Kościoła.

Po wznowieniu kapituły kolegiackiej w Wieluniu biskup Stefan Bareła powierzył mu godność prałata-dziekana tejże kapituły, na którą otrzymał bullę nominacyjną pap. Pawla VI datowaną dnia 1 grudnia $1965 \mathrm{r}$. Trzeci biskup częstochowski, pismem z dnia 14 marca 1966 r., powierzył mu obowiązek zorganizowania zespolu redakcyjnego celem opracowania dziejów diecezji częstochowskiej, a także przygotowanie opracowań kultu maryjnego w Wieluniu i w Dąbrowie Górniczej. W dniu 10 marca $1969 \mathrm{r}$. przedłożył biskupowi materiały historyczne dotyczące kultu Matki Bożej Pocieszenia w Wieluniu. W związku z obchodami 50-lecia istnienia diecezji częstochowskiej wziął czynny udzial $w$ opracowaniu katalogu diecezjalnego piszac dzieje parafii $w$ dekanatach bolesławieckim, praszkowskim, wieluńskim I, wieluńskim II i wieruszowskim. Obok stanowiska archiwariusza był także sędzią w miejscowym Sądzie Biskupim. Latem $1980 \mathrm{r}$. stan jego zdrowia uległ znacznemu pogorszeniu. Poddal się wówczas operacji, po przeprowadzeniu której czul się dobrze. Jednakże jesienią znów zachorował (źóltaczka). Tym razem leczenie szpitalne nie dało już pozytywnych wyników. Po powrocie do własnego mieszkania w Domu Księży Emerytów w Częstochowie, gdzie od wielu lat mieszkał, mimo cierpnienia jeszcze zachowywal pogodę ducha. W ostatnich dniach życia zachowywał świadomość swego kapłaństwa. W wigilię Bożego Narodzenia już nie rozumial składanych mu życzeń świątecznych. Zmarł w godzinach rannych $w$ Boże Narodzenie $1980 \mathrm{r}$. Pogrzeb odbyl się $w$ dniu 27 grudnia tr. W uroczystościach pogrzebowych wziął udział biskup ordynariusz Stefan Barela wraz z biskupami pomocniczymi i licznie przybyłymi kapłanami, siostrami zakonnymi i wiernymi. Pochowany zostal na cmentarzu grzebalnym w Praszce. Przemówienie załobne wygłosif ksiądz prałat Leon Stasiński.

Zmarły ksiądz prałat dr Walenty Patykiewicz był organizatorem Archiwum Diecezjalnego w Częstochowie. W ciągu kilkudziesięciu lat pracy na stanowisku archiwariusza gromadził akta zarówno z terenu diecezji częstochowskiej, jak i dawne archiwalia w diecezji kieleckiej i włocławskiej, dotyczące przeszłości kościelnej terenów diecezji częstochowskiej. Wśród zebranych archiwaliów $z$ diecezji najwięcej było ksiąg metrykalnych, chociaż jeszcze nie wszystkie zostały przez niego zgromadzone. Przy Archiwum Diecezjalnym gromadził także podręczny księgozbiór, stanowiący pomoc przy opracowywaniu materiałów aktowych. Przez wiele lat gromadzil materiaky do dziejów poszczególnych parafii i miejscowości w diecezji częstochowskiej. Pozostawił także w maszynopisie kilkanaście opracowań poświęconych dziejom parafii, szczególnie $w$ ziemi wieluńskiej. Ponadto w okresie kilku lat sprawowal opiekę nad ksiegozbiorem diecezjalnym w Częstochowie.

Działalność pisarską rozpocząl jeszcze w latach studiów seminaryjnych we Wlockawku pod kierunkiem ks. prof. Michała Morawskiego i kontynuowal ją aż do ostatnich lat życia. Opracowywal przeważnie zagadnienia do- 
tyczące przeszłości diecezji częstochowskiej. Znaczną część tej pracy stanowiły biogramy zmarłych kaplanów. Poniżej został podany wykaz prac drukowanych ks. dra Walentego Patykiewicza w ukladzie chronologicznym.

1928

1. Zarys dziejów Seminarium Duchownego we Wloclawku. "Przedświl". Kwal'talnik Polskiej Mlodzieży Duchownej. R. 10; 1928, s. 33-39; R. 11: 1929, s. $7-12,63-69,142-147$; R. 12: 1930, s. 15-19, s. 59-60, 99-102.

\section{5}

2. Nieco o starej Ziemi Wieluńskiej. „Kalendarz Jasnogórski... 1935”, kol. 207 -216 .

\section{7}

3. Redakton: Katalog kościolów i duchowieństwa diecezji częstochowskiej na rok 1947. Czesstochowa 1947, ss. 191.

4. Redaktor: Ordo divini officii recitandi sacrique peragendi.. 1947. Częstochowa 1947, ss. 192.

\section{8}

5. Redaktor: Ordo divini officii recitandi sacrique peragendi... 1948. Kraków 1947 , ss. 180.

\section{9}

6. Redaktor: Ordo divini officii recitandi sacrique peragendi... 1949. Częstochowa 1949, ss. 161.

\section{0}

7. Redaktor: Ordo divini officii recitandi sacrique peragendi.. 1950. Czestochowa 1949 , ss. 153.

\section{1}

8. Redaktor: Katalog kościołów i duchowieństwa diecezji częstochowskiej na rok 1951 [na powielaczu], ss. 113.

9. Redaktor: Ordo divini officii recitandi sacrique peragendi... 1951. Katowice 1951 , ss. 89.

\section{2}

10. Redaktor: Ordo divini officii recitandi sacrique peragendi... 1952 [na powielaczu], ss. 128.

\section{3}

11. Redaktor: Ordo divini officii recitandi sacrique peragendi... 1953. Częstochowa 1952 , ss. 154.

\section{6}

12. Statuty kolegiaty rudzko-wieluńskiej. „Rocz. teol.-kanon.”. R. 3: 1956, s. 347-376 . 


\section{7}

13. Archidiakonat wieluniski. "Wiad. diec. Czest. Kurii". R. 24/31: 1957, s. 383-393, 425-433, 455-465, 493-505; „Częst. Wiad, diec.”. R. 32: 1958, s. 28-38, 72-80, $111-120,156-160,194-212,237-248,275-283,462-469$.

14. Nie znany dolument ks. Wladyslawa Wroctauskiego z $1267 \%$, Rocz. teol.-kanon.". R. 3: 1957, z. 2, s. 390-394.

\section{8}

15. Wspóluedahtor: Katalog kościolón $i$ duchowienstwa diecezji częstochowskiej [na rolc] 1958. Czestochowa 1958, ss. 260, nlb. 6.

16. Późniejsze oficjalaty gnieźnieńskie. „Rocz. teol.-kanon.”. R. 4: 1958, z. 4, s. 117-122 .

17. Księga squlowa-kopiarz krzepicki „Rocz. teol--kanon.”. R. 4: 1958, z. 5, S. 139$-143$.

\section{1}

18. Z przeszlości Ziemi Rudzkiej. „Częst. Wiad. diec.”. R. 35: 1961, s. 117-128.

19. Cześć Bogarodzicy Dziewicy w obrazach i rzé́bach na terenie diecezji częstochowskivi. ,Częst. Wiad. diec.”. R. 35: 1961, s. 158-159.

\section{2}

20. Ks. Bartlomiej Ludwik Michalski (1871-1930). „Częst. Wiad. diec.”. R. 36: 1962 , s. 123.

21. Ks. Zygmunt Drejer (1858-1930). „Czest. Wiad. diec.”. R. 36: 1962, s. $123-124$.

22. Ks. Antoni Zagrzejewski (1859-1930). „Częst. Wiad. diec.”. R. 36: 1962, s. 124$-125$.

23. Ks. Wincenty Zamojski (1872-1930). „Częst. Wiad. diec.”. R. 36: 1962, s. 152.

24. Ks. Jan Strzelecki (1898-1930). „Częst. Wiad. diec.”. R. 36: 1962, s. 152-153.

25. Ks. Wackaw Szczotkowski (1872-1930). „Częst. Wiad. diec.”. R. 36: 1962, s. 153.

26. Ks. Bronisław Swiezewski (1870-1932). "Częst. Wiad. diec." R. 36: 1962, s. 219.

27. Ks. Jan Czok (1849-1933). „Częst. Wiad. diec.”. R. 36: 1962, s. 219-220.

28. Ks. Stanistaw Mazurkiewicz (1869-1933). „Częst. Wiad. diec.”. R. 36: 1962, s. $220-221$.

29. Ks. Zygmunt Sedzimir (1881-1933). „Częst. Wiad. diec.”. R. 36: 1962, s. $221-222$.

30. Ks. Waclaw Kokowoski (1862-1934). „Częst. Wiad. diec.”. R. 36; 1962, s. 222.

31. Ks. Franciszek Michat Marekwia (1891-1931). „Czest. Wiad. diec.”. R. 36: 1962, s. $249-250$.

32. Ks. Mikolaj Libura (1863-1931). „Częst. Wiad, diec.”. R. 36: 1962, s. 250.

33. Ks. Józef Eogucki (1871-1931), „Częst. Wiad, diec.”. R. 36: 1962, s. 250-251.

34. Ks. Franciszek Ksawery Plenkiewicz (1867-1932). „Częst. Wiad. diec.”. R. 36: 1962 , s. $251-252$.

\section{3}

35. Ks. Bolestaw Szymanowski (1880-1936). „Czçst. Wiad. diec.”. R. 37: 1963, s. $54-55$.

36. Ks. Jan Smużyński (1863-1935). „Częst. Wiad. diec.”. R. 37: 1963, s. 55-56.

37. Ks. Julian Dobroszaw Zielinski (1905-1934). „Częst. Wiad. diec.". R. 37: 1963, s. 56 .

38. Ks. Antoni Zmystowski (1872-1935). „Częst. Wiad. diec.”. R. 37: 1963, s. 56. 
39. Ks. Antoni Józef Christoph (1878-1933). „C\%est. Wiad. diec.”. R. 37: 1963, s. $100-101$.

40. Ks. Wincenty Wojciechowski (1881-1934). "Częst. Wiad. diec.”. R. 37: 1963, s. 101.

\section{4}

41. Ks. Franciszek Kalinowski (1879-1936). „Częst. Wiad. diec.”. R. 38: 1964, s. $119-120$.

42. Ks. Jan Strzelecki (1872-1936). „Częst. Wiad. diec.”. R. 38: 1964, s. 120.

43. Ks. Wladystaw Ptaszyński (1877-1936). „Częst. Wiad. diec.”. R. 38: 1964, s. $120-121$.

44. Ks. Ignacy Mariankowski (1884-1936). "Częst. Wiad. diec.". R. 38: 1964, s. 121.

45. Ks. Mikolaj Lubowidzki (1880-1937). "Częst. Wiad. diec.”. R. 38: 1964, s. 202.

46. Ks. Józef Zaborski (1876-1937). „Częst. Wiad. diec.”. R. 38: 1964, s. 203.

47. Ks. Antoni Grochowski (1860-1937). „Częst. Wiad, diec.”. R. 38: 1964, s. 204.

48. Ks. Kazimierz Henryk Mazurkiewicz (1878-1939). "Częst, Wiad. diec.” R. 38: 1964 , s. 204-205.

49. Ks. Witalis Walenty Grzeliński (1879-1939). „Częst. Wind. diec.”. R. 38: 1964, S. 205 .

50. Ks. Wladyslaw Tomalka (1898-1938). „Częst. Wiad. diec.”. R. 38: 1964, s. 241-242 .

51. Ks. Ignacy Lachowicz (1879-1938). „Częst. Wiad. diec.”. R. 38: 1964, s. 242.

52. Ks. Jan Dudzik (1883-1939). „Częst. Wiad. diec.”. R. 38: 1964, s. 243.

\section{5}

53. 700-lecie parafii Krzyworzelka. "Częst. Wiad. diec.”. R. 39: 1965, s. 214-215.

\section{6}

54. Kalendarzowy wykaz odpustów w kościołach diecczji częstochowskiej. "Częst. Wiad. diec.". R. 40: 1966, s. 19-23.

55. Chronologia parafii diecezji częstochowskicj. „Częst. Wiad. diec.”. R. 40: 1966, s. $63-72$.

\section{$196 \%$}

56. Ks. Biskup Stanisław Czajka. „Zesz. nauk. KUL”. R. 10: 1967, z. 3(39), s. 93-94.

57. Ks. Michat Ciesielski (1870-1936). "Częst. Wiad. diec.”. R. 41: 1967, s. 188-189.

58. Ks. Aleksander Gostyński (1881-1936). „Czest. Wiad. diec.”. R. 41: 1967, s. 189.

50. Ks. Edward Bentkowski (1877-1939). "Częst. Wiad. diec.”. R. 41: 1967, s. 100.

60. Ks. Zygmunt Cyryl Jędrzycki (1889-1939). „Częst. Wiad. diec.”. R. 41: 1967, s. 190 .

\section{8}

61. Wspólredaktor: Katalog kościolów i duchowieństwa diecezji częstochowskiej [na rok] 1968. Częstochowa 1968, sss. 358.

\section{9}

62. Powstanie Archiwum Diecezjalnego w Częstochowie. "Częst. Wiad. diec.”. R. 43: 1969, s. $91-94$.

63. Kościól parafialny w Przyrowie. „Częst. Wiad. diec.”. R. 43: 1969, 's. 160-167. 


\section{1}

64. Wspólautor: Obraz Matki Bożej Pocieszenia w kolegiacie wieluńskiej. „Częst. Wiad. diec.". R. 45: 1971, s. 107-115.

\section{8}

65. Wspólredaktor: Katalog kościołów $i$ duchowieństwa diecezji częstochowskiej [na rok] 1978. Częstochowa 1978, ss. 638. 